\title{
Estimating Milk Production in Ardahan Province with ARIMA (Box- Jenkins) Model
}

\author{
Özlem EŞTÜRK ${ }^{1}$ \\ ${ }^{1}$ Asst. Prof. Dr., Ardahan University, Faculty of Economics and Administrative Sciences, Department of \\ Economics, Ardahan, Turkey
}

Geliş Tarihi/Received: 16.07.2021

Kabul Tarihi/Accepted: 07.09.2021
Doi:10.31200/makuubd.972489

Araştırma Makalesi/Research Article

\section{ABSTRACT}

Economy of Ardahan province on a large scale depends on stock farming since a significant part of the population is employed in the livestock sector. For this reason, milk and dairy products have an important place in Ardahan's economy. The increasing demand for milk in Turkey and in the World brings the issue of sustainability of milk supply. Therefore, it is important to estimate the proceeding course of milk production to adapt increasing milk demand and to determine effective policies. In the study, Ardahan province milk production data was obtained from Turkish Statistical Institute (TUIK) for the period of 1995-2019 in order to estimate the milk production. Box-Jenkin's methodology was used to predict milk production of Ardahan province for the years of 2020-2025. A suitable ARIMA $(0,0,1)$ model was proposed to forecast estimate milk production of Ardahan province. According to this model, the milk production in Ardahan province was estimated as 414, 439 and 557 thousand tons in 2020, 2021 2025, respectively.

Keywords: Milk Production, ARIMA, Estimate.

\section{Ardahan İli Süt Üretiminin ARIMA (Box-Jenkins) Modeli ile Tahmini ÖZET}

Nüfusun önemli bir kısmının hayvancılık sektöründe istihdam edildiği Ardahan'da ekonomi, büyük ölçüde büyükbaş hayvancılığa dayanmaktadır. Bu nedenle Ardahan ekonomisinde süt ve süt ürünleri önemli bir yere sahiptir. Türkiye ve dünyada süte olan talebin, her geçen gün artması, süt arzının sürdürülebilirliği konusunu gündeme getirmektedir. Dolayısıyla artan talep 
artışına uyum sağlanması ve etkin politikaların belirlenmesinde, gelecekteki süt üretiminin nasıl bir seyir göstereceğine ilişkin tahminler önem taşımaktadır. Çalışmada, Ardahan ilinin süt üretiminin tahmin edilmesi amacıyla Türkiye İstatistik Kurumu'ndan (TÜİK) 1995-2019 yıllar1 için süt üretim verileri alınmıştır. Ardahan ili süt üretiminin tahmininde 2020-2025 yılları için Box-Jenkins yöntemi kullanılmış ve ARIMA $(0,0,1)$ modelinin uygun olduğu görülmüştür. Bu modele göre, Ardahan ili süt üretiminin 2020 yılında 414 bin ton, 2021 yılında 439 bin ton, 2025 yılında ise 557 bin ton olacağ tahmin edilmiştir.

Anahtar kelimeler: Süt Üretimi, ARIMA, Tahmin.

\section{INTRODUCTION}

TRA2 region (Ardahan, A ğrı, Iğdır and Kars) is the least developed and industrialized region in Turkey. Share of industry in gross domestic product (GDP) is low for this region due to its remote geographical location, the absence of qualified workforce, insufficient capital accumulation, distance to the market, and harsh climatic conditions. Economy of this region and Ardahan is predominantly based on the livestock sector. Therefore, livestock sector is important at the strategic level for this region. The livestock sector is the locomotive of rural development since it provides high added value per unit investment and creates employment opportunities with low capital investments (Kutlu et al., 2003).

Milk is one of the most important products of cattle farming. In addition to providing income support to farmers, it creates an important source of income by creating employment opportunities for farmers who have no land. As milk production is a strategic product in terms of both supply and demand, future projections are important in policy makers' short and longterm planning (Ahmed et al., 2011).

Milk production in Ardahan province is 425 thousand tons in 2019 (Turkish Statistical Institute [TÜIKK], 2020), having an important share in milk production of the TRA2 region. Average milk yield from cattle is low in the TRA2 region due to poor care and feeding conditions. Cattle spend less time in the pastures due to harsh climatic conditions which in turn increases the staying time in the barn and consumption of more feed. The main problems of stock farmers are high feed costs and decrease in the forage plant production capacity of pastures as a result of climate change. The presence of native breeds in the region is among the factors reducing milk yield (Bakır \& Kibar, 2019; Şeker et al., 2012). 
Stock farming is still carried out with traditional methods in Ardahan province and TRA2 region. This situation adversely affects milk quality and the fight against animal diseases. Therefore, establishment of modern infrastructure and application of modern techniques are necessary for the production at international standards.

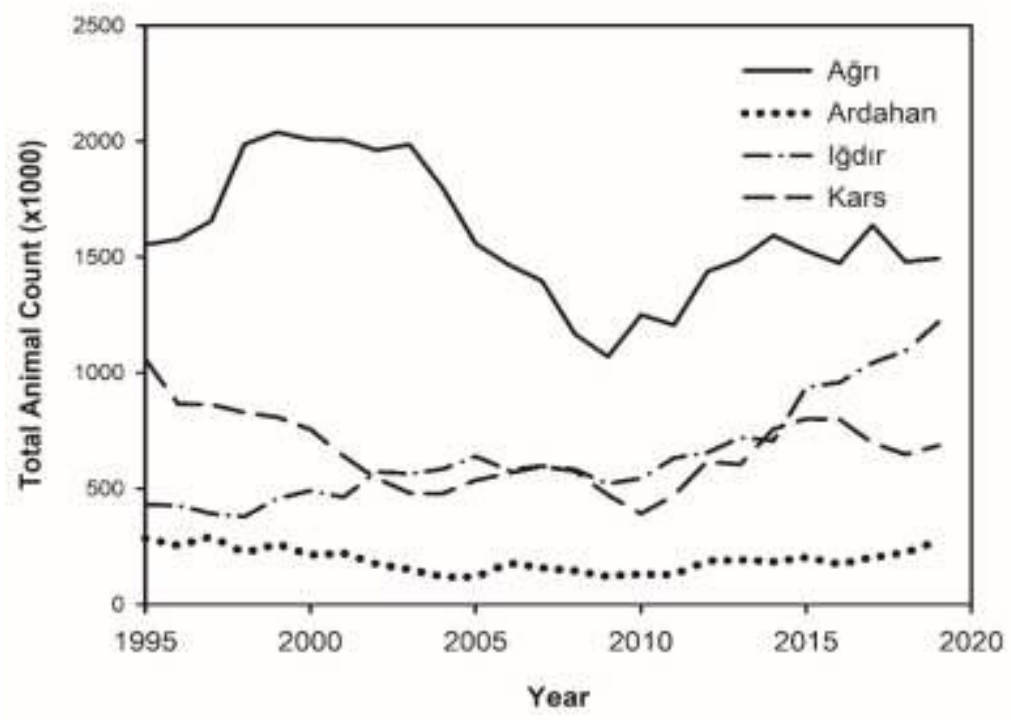

Figure 1. TRA2 Total number of milker animals in the region (TÜİK, 2020)

Figure 1 shows the number of milker animals in the TRA2 Region. While Ardahan province ranks last in the TRA2 region in milker animals, it ranks second in milk production (Figure 2) and first in milk productivity (Figure 3).

Milk production is increased over the years in the TRA2 region even though the number of milker animals have not been increased. The sustainability of increase in milk production depends on the income increase of stock farmers. In this context, it is important for the stock farmers to obtain a satisfactory profit from milk production and to transform milk into high added value products.

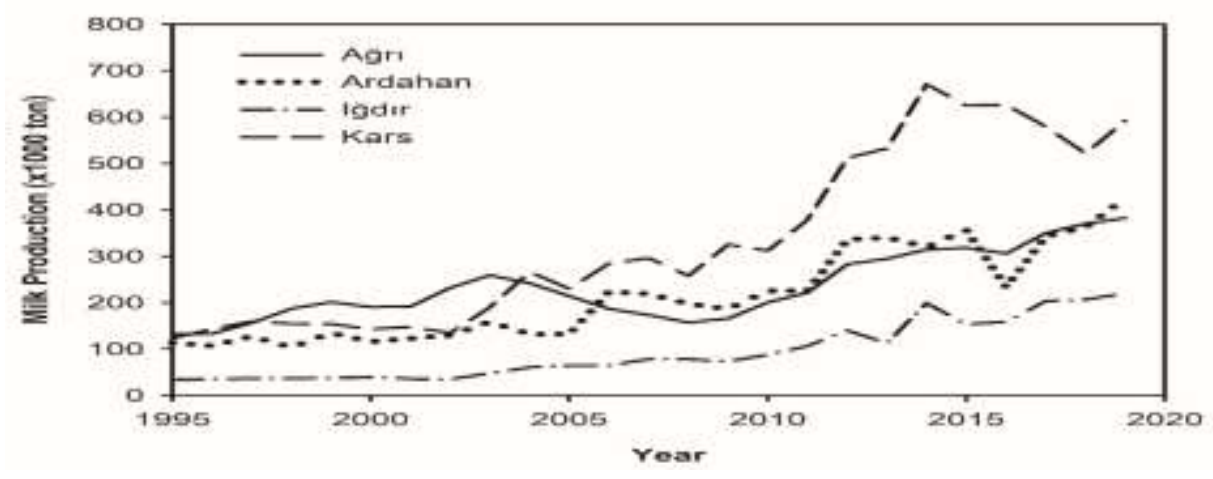

Figure 2. Milk production in the TRA2 region (TÜİK, 2020) 


\section{Eștürk, $\ddot{O}$.}

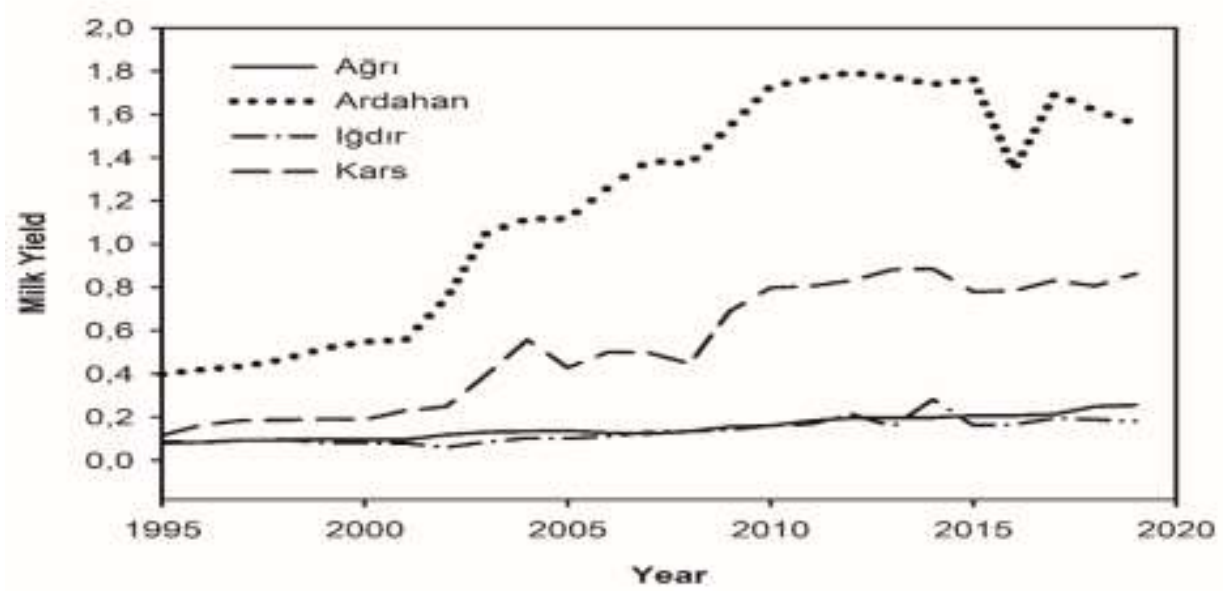

Figure 3. Efficiency in total milk production (TÜİK, 2020)

In terms of milk productivity Ardahan ranks first in the TRA2 Region (Figure 3). Ardahan has a high milk production potential due to its fertile and broad pastures.

Although the number of cattle has decreased in recent years, there has been a limited increase in milk yield throughout Turkey. It is due to the success of breeding animal imports and breeding practices (İçöz, 2004).

Stock farming has an important place in the provincial economy. Approximately $34 \%$ of the GDP of Ardahan province was provided by the agricultural sector, the second income generating sector after the service sector (Figure 3). The low level of agricultural industry prevents the animal products turned into value added products.

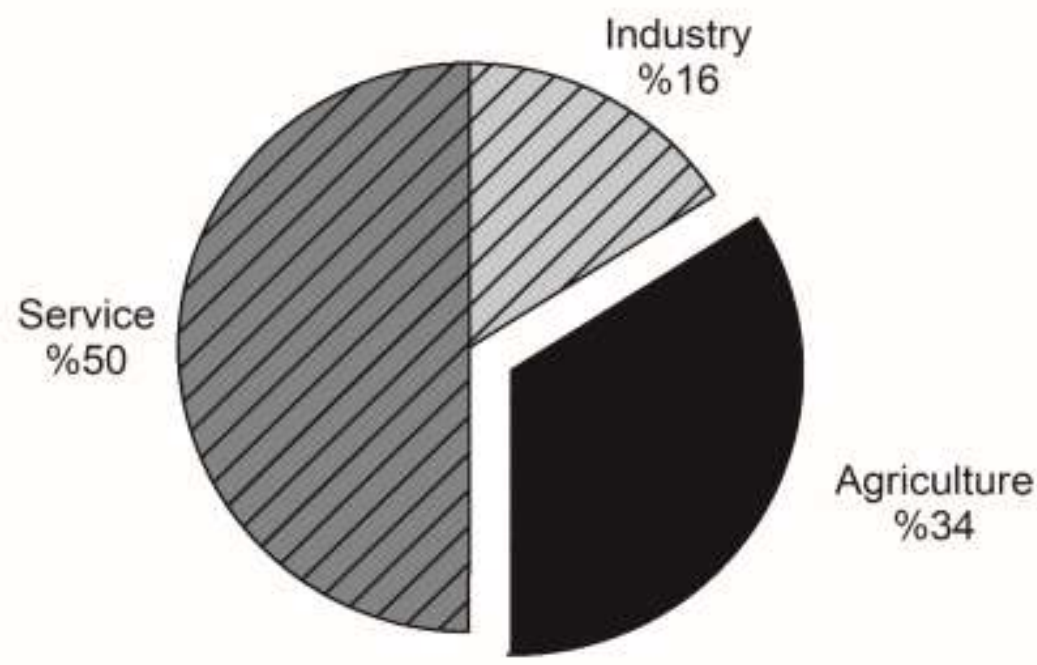

Figure 4. Economic activity sectoral distribution of GDP in Ardahan province (TÜIK, 2020). 


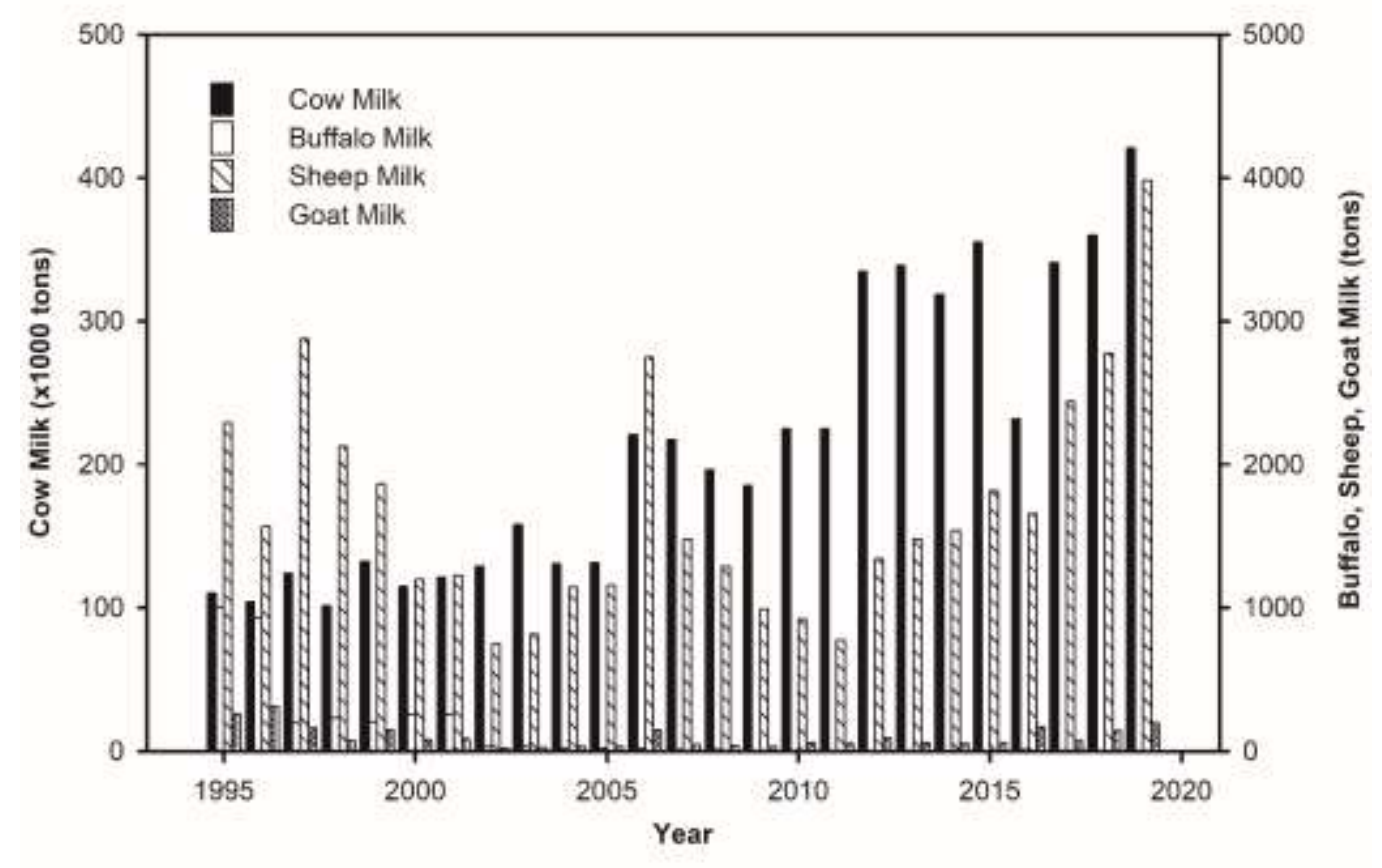

Figure 5. Milk production in Ardahan from different animal species (TÜİK, 2020)

The share of milk production in Ardahan province from different animal species is shown in Figure 5. Cow milk production was much higher than other animal species. Even though there were some fluctuations, cow milk production increased steadily from 1995 to 2019.

In this study, it is aimed to estimate the milk production of Ardahan province until 2025 with the help of ARIMA model. Such studies will reveal beneficial results for other stakeholders in the sector, especially milk producers.

\section{LITERATURE REVIEW}

Başaran and Engindeniz (2020) studied the fiber cotton production in Turkey for the years 1991-2018 and estimated cotton production for the next five years using ARIMA $(4,1,4)$ model. Özen et al. (2019) studied meat consumption per capita by Box Jenkins and exponential smoothing models for the years from 1993 to 2017. Estimation was made according to ARIMA $(0,1,0)$ and Brown models, it was concluded that the demand for meat consumption was going to increase in Turkey.

Kurt and Karay1mazlar (2018) estimated the mushroom production in Turkey with the ARIMA (3,2,1) model based on the 1985-2016 period. They concluded that mushroom production would follow an increasing trend. Bars et al. (2018) estimated hazelnut production 
in Turkey with ARIMA and they concluded that the best model was ARIMA $(1,2,2)$ model and predicted a fluctuating production for hazelnut. Celik et al. (2017) used ARIMA to estimate peanut production in Turkey for the period of 1950-2015 and stated that the best fit model was ARIMA $(0,1,1)$. In the study of Mgaya (2019), animal product consumption in Tanzania for the years 1961-2013 was estimated by ARIMA and Brown exponential smoothing model.

\section{DATA SET AND METHOD}

\subsection{Data Set}

ARIMA model was used to estimate the milk production of Ardahan province, milk production data of the annual data set from 1995 to 2019. The data set was obtained from the regional statistics database of the Turkish Statistical Institute (TÜİK, 2020).

\subsection{Method}

Box Jenkins ARIMA (p,d,q) model proposed by Box and Jenkins (Box et al., 2015), is one of the common methods used to create the univariate time series forecasting model (Mensah, 2015). The ARIMA model, a mathematical approach to predict a process, was developed by George Box and Gwilym Jenkins in the 1970s. Box-Jenkins modeling involves completing an appropriate ARIMA process, fitting it to the data, and then using the appropriate model for prediction. One of the advantages of this model is that ARIMA operations contain numerous models and generally provide sufficient explanation for the data (Hyndman, 2001).

A non-seasonal ARIMA model is denoted by ARIMA (p,d,q), which is a combination of autoregressive (AR) and moving average (MA) and the order of integration or differentiation. Here, $d$ represents the difference, $p$ correlation and q moving average coefficients (Dasyam et al., 2015).

Autoregressive models are models in which the value of a variable in one period is related to its value in previous periods. The autoregressive process at the $\mathrm{p}$ level is expressed by $\operatorname{AR}(p)$ and is expressed as in equation 1.

$$
A R(p): Y t=\beta 0+\Sigma \beta i Y t-i p i=1+\epsilon t
$$

Moving average models, on the other hand, are models in which there is a relationship between a variable and residuals from the previous period. The moving average model at the $p$ level is expressed as MA(p) and shown as in equation 2. 
$M A(q): Y t=\alpha 0+\epsilon t+\Sigma \alpha i \epsilon t-i q i=1$

ARMA models are the combination of the two processes mentioned above. A process consisting of autoregressive term (p) and moving average term (q) is shown in equation 3 as $\operatorname{ARMA}(\mathrm{p}, \mathrm{q})$.

$$
A R M A(p, q): Y t=\beta 0+\Sigma \beta i Y t-i p i=1+\epsilon t+\Sigma \alpha i \epsilon t-i q i=1
$$

Time series should be stationarity to use these models for an estimation. There is no trend in stationary processes since mean and variance do not change over time. In the process of estimating ARMA (p, q) models, non-stationary series mathematically transformed into stationary series by taking the difference. A series that becomes stationary when its first difference is taken, denoted by I (1). The combination of all these processes creates integrated moving average (ARIMA) models.

\subsection{Testing the Stationarity of the Series}

The stationarity of the series was tested first to conduct the time series analysis. The unit root test results of the series are given in Table 1.

Table 1. ADF unit root test results

\begin{tabular}{|c|c|c|c|}
\hline \multicolumn{2}{|l|}{ Test } & \multirow{2}{*}{$\frac{t-\text { Statistics }}{-6.557295}$} & \multirow{2}{*}{$\frac{\text { Significance }}{0.0000}$} \\
\hline ADF Statistics & & & \\
\hline \multirow[t]{3}{*}{ Critical Values } & $\% 1$ & -2.669359 & \\
\hline & $\% 5$ & -1.956406 & \\
\hline & $\% 10$ & -1.608495 & \\
\hline
\end{tabular}

To determine the best fitting model for estimating of the amount of milk production, various models were tested. The best model explaining the series was chosen for having Theil equality coefficient below 1 and the lowest Mean Absolute Percent Error (MAPE), Akaike Criterion, Hannan-Qinn and Schwarz Criterion values among the models (Başaran \& Engindeniz, 2020; Güler et al., 2017). These values of the predicted models were shown in Table 2. Among these models, ARIMA $(0,0,1)$ model was chosen for having the lowest AIC, BIC and HQ values. Statistical values for ARIMA $(0,0,1)$ model were given in Table 3. 
Table 2. ARIMA models statistics for milk production

\begin{tabular}{|lllll|}
\hline Model & LogL & AIC* & BIC & HQ \\
\hline$(0,0,1)$ & 69.481059 & -5.540088 & -5.392832 & -5.501021 \\
$(1,0,1)$ & 69.613348 & -5.467779 & -5.271437 & -5.415689 \\
$(0,0,2)$ & 69.612362 & -5.467697 & -5.271355 & -5.415607 \\
$(0,0,3)$ & 69.625054 & -5.385421 & -5.139993 & -5.320309 \\
$(2,0,1)$ & 69.618779 & -5.384898 & -5.139470 & -5.319786 \\
$(1,0,2)$ & 69.614565 & -5.384547 & -5.139119 & -5.319435 \\
$(3,0,1)$ & 70.075264 & -5.339605 & -5.045092 & -5.261471 \\
$(0,0,4)$ & 70.029227 & -5.335769 & -5.041255 & -5.257634 \\
$(2,0,2)$ & 69.649218 & -5.304102 & -5.009588 & -5.225967 \\
$(1,0,3)$ & 69.635580 & -5.302965 & -5.008452 & -5.224831 \\
$(1,0,4)$ & 70.354728 & -5.279561 & -4.935962 & -5.188404 \\
$(1,0,0)$ & 66.186886 & -5.265574 & -5.118317 & -5.226507 \\
\hline
\end{tabular}

Table 3. Estimation of the selected model

\begin{tabular}{|lllll|}
\hline Variable & Coefficient & Std. Error & t-Statistic & Prob. \\
\hline C & 5.290466 & 0.049456 & 106.9741 & 0.0000 \\
MA(1) & 0.741596 & 0.268968 & 2.757191 & 0.0115 \\
SIGMASQ & 0.019749 & 0.007680 & 2.571528 & 0.0174 \\
\hline R-squared & 0.487952 & Mean dependent var & 5.283835 \\
Adjusted R-squared & 0.441403 & S.D. dependent var & 0.200439 \\
S.E. of regression & 0.149807 & Akaike info criterion & -0.814834 \\
Sum squared residual & 0.493727 & Schwarz criterion & -0.668569 \\
Log likelihood & 13.18543 & Hannan-Quinn criter. & -0.774267 \\
F-statistic & 10.48238 & Durbin-Watson stat & 1.125543 \\
Prob(F-statistic) & 0.000634 & & \\
\hline
\end{tabular}

The results of unit root test applied to error terms of the ARIMA $(0,0,1)$ showed that model he suitable according to ADF and Phillips and Perron tests (Table 4). 
Theil inequality coefficient was calculated as 0.308 in the ARIMA $(0,0,1)$ model indicating that the estimation error rate is low and it fits the model well.

Table 4. ADF and Phillips-Perron test

\begin{tabular}{|llll|}
\hline & & t-Statistic & Prob.* $^{*}$ \\
\hline Augmented Dickey-Fuller test statistic & -9.715792 & 0.0000 \\
\hline Test critical values: & $1 \%$ level & -4.394309 & \\
& $5 \%$ level & -3.612199 & \\
& $10 \%$ level & -3.243079 & \\
\hline & & Adj. t-Stat & Prob.* \\
\hline Phillips-Perron test statistic & & -9.758205 & 0.0000 \\
\hline Test critical values: & $1 \%$ level & -4.394309 & \\
& $5 \%$ level & -3.612199 & \\
& $10 \%$ level & -3.243079 & \\
\hline
\end{tabular}

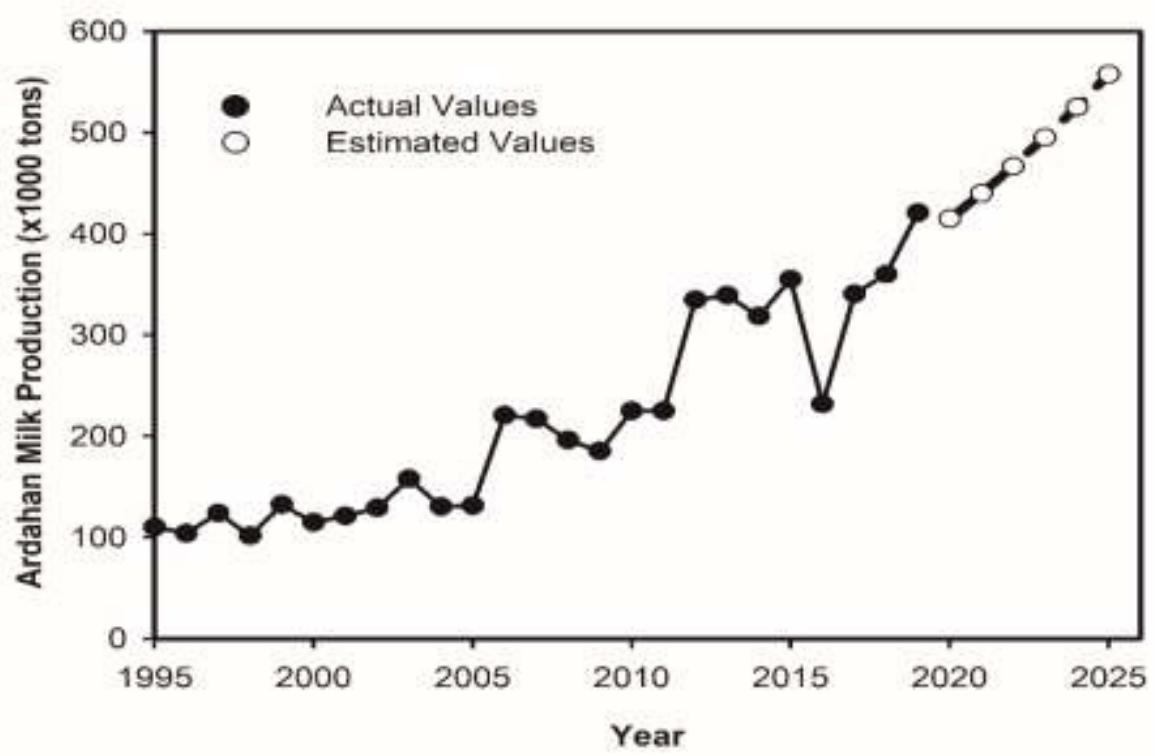

Figure 6. Milk production trend of Ardahan province for the period of 1995-2025

After the conducting compliance, milk production amount was estimated for Ardahan province. According to the ARIMA $(0,0,1)$ model, it is estimated that milk production in Ardahan will increase over the years. Milk production in Ardahan province was estimated as 


\section{Eştürk, $\ddot{O}$.}

414 thousand tons in 2020 and 557 thousand tons in 2025, an increase of $31.05 \%$ compared to 2019.

\section{CONLUSION}

In this study, milk production of Ardahan province was estimated using the ARIMA model for the period 1995-2019. The data set was obtained from the regional statistics database of the Turkish Statistical Institute (TUIK). ARIMA $(0,0,1)$ model was used to estimate the milk production of Ardahan province for the years of 2020-2025. Milk production in Ardahan was estimated as 414, 439, 466, 495, 525, 557 thousand tons for 2020, 2021 2022, 2023, 2024 and 2025 , respectively.

Projected increase in the amount of milk production in Ardahan province would affect milk and cheese producers. Forecasting milk production in Ardahan may help in production and future investment planning of the Kashar cheese producers, which are prominent in dairy sector. Increases in milk production would increase capacity utilization of enterprises producing Kashar cheese, where a significant part of them works under their capacity. The spread of studies on the estimation of milk production, a strategic product for the Ardahan economy, is important for the future of the sector.

\section{REFERENCES / KAYNAKLAR}

Ahmed, F., Shah, H., Raza, I., \& Saboor, A. (2011). Forecasting milk production in Pakistan. Pakistan Journal of Agricultural Research, 24(1-4), 82-85.

Bakır, G., \& Kibar, M. (2019). Muş ilinde bulunan süt sığırcılığı işletmelerinin bazı yapısal özelliklerinin Crostabb analiziyle belirlenmesi. Kahramanmaraş Sütçü Imam Üniversitesi Tarım ve Doğa Dergisi, 22(4), 609-619. https://doi.org/10.18016/ksutarimdoga.vi.455439

Bars, T., Uçum, İ., \& Akbay, C. (2018). ARIMA modeli ile Türkiye fındık üretim projeksiyonu. Kahramanmaraş Sütçü Imam Üniversitesi Tarım ve Doğa Dergisi, 21, 154-160. https://doi.org/ksutarimdoga.v21i41625.473029

Başaran, C., \& Engindeniz, S. (2020). Türkiye'de pamuk üretiminin ARIMA modeli ile tahmini. Tarım Ekonomisi Dergisi, 26(1), 63-70.

Box, G. E., Jenkins, G. M., Reinsel, G. C., \& Ljung, G. M. (2015). Time series analysis: Forecasting and control. John Wiley \& Sons.

Celik, S., Karadas, K. \& Eyduran, E. (2017). Forecasting the production of Groundnut in Turkey using Arima model. The Journal of Animal and Plant Sciences, 27(3), 920-928.

Dasyam, R., Pal, S., Rao, V. S., \& Bhattacharyya, B. (2015). Time series modeling for trend analysis and forecasting wheat production of India. International Journal of Agriculture, Environment and Biotechnology, 8(2), 303-308. https://doi.org/10.5958/2230-732X.2015.00037.6 
Güler, D., Saner, G., \& Naseri, Z. (2017). Yağlı tohumlu bitkiler ithalat miktarlarının arıma ve yapay sinir ağları modeliyle tahmini. Balkan ve Yakın Doğu Sosyal Bilimler Dergisi, 3(1), 60-70.

Hyndman, R. J. (2001). Box-Jenkins modelling. Regional Symposium on Environment and Natural Resources, Apr.

İçöz, Y. (2004). Bursa ili süt sı̆̆ırcılık işletmelerinde karlılık ve verimlilik analizi. TC Tarım ve Köyişleri Bakanlığı Tarımsal Ekonomi Araştırma Enstitüsü, Yayın No 116, Ankara.

Kurt, R., \& Karayılmazlar, S. (2018). Türkiye mantar üretimi ve ARIMA (Box-Jenkins) ile projeksiyonu. Ormancılık Araştırma Dergisi, 6(1), 72-76.

Kutlu, H. R., Gül, A., \& Görgülü, M. (2003). Türkiye hayvancılı̆̆ı; hedef 2023-sorunlar, çözümyollarl ve politika arayışlarl. Retrieved from: 15.05.2021, http://www.zootekni.org.tr/upload/File/Hayvanclk\%20Rapor-Sonhali.pdf

Mensah, E. K. (2015). Box-Jenkins modelling and forecasting of Brent crude oil price. M. P. R. A. P. N. 67748. https://mpra.ub.uni-muenchen.de/67748/

Mgaya, J. F. (2019). Application of ARIMA models in forecasting livestock products consumption in Tanzania. Cogent Food and Agriculture, 5(1), 1607430. https://doi.org/10.1080/23311932.2019.1607430

Özen, D., Tekindal, M. A., \& Çevrimli, M. B. (2019). Modeling and forecasting meat consumption per Capita in Turkey. Erciyes Üniversitesi Veteriner Fakültesi Dergisi, 16(2), 122-129. https://doi.org/https://doi.org/10.32707/ercivet.595626

Şeker, İ., Tasalı, H., \& Güler, H. (2012). Muş ilinde sı̆̆ır yetiştiriciliği yapılan işletmelerin yapısal özellikleri. Fırat Üniversitesi Să̆llk Bilimleri Veteriner Dergisi, 26(1), 9-16.

TÜİK.

(2020).

Bölgesel

istatistikler.

https://biruni.tuik.gov.tr/bolgeselistatistik/degiskenlerUzerindenSorgula.do?d-4326216-p=2 